\title{
PILEATED WOODPECKERS NEST IN THE SASKATOON DISTRICT
}

JIM A. WEDGWOOD, 610 Leslie Avenue, Saskatoon, Saskatchewan. S7H 2 Z2

Four of 12 observations of Pileated Woodpeckers in the Saskatoon district up to 1987 were in the breeding season. That year the area's first known nest was discovered. This event was unusual for locale and distance from known breeding sites to the north, as well as for rarity.

On 30 April a pair of these large woodpeckers was cavorting around a hole in the east side of a big, old, fire-scarred snag. The site was on the south bank of the North Saskatchewan River north of Asquith. As the pair shimmied and hitched around the hole, sometimes touching bills in courtship display, their large erect crests flashed a brilliant red in the early morning sun. Spectacular!

Two days later the Wedgwoods were

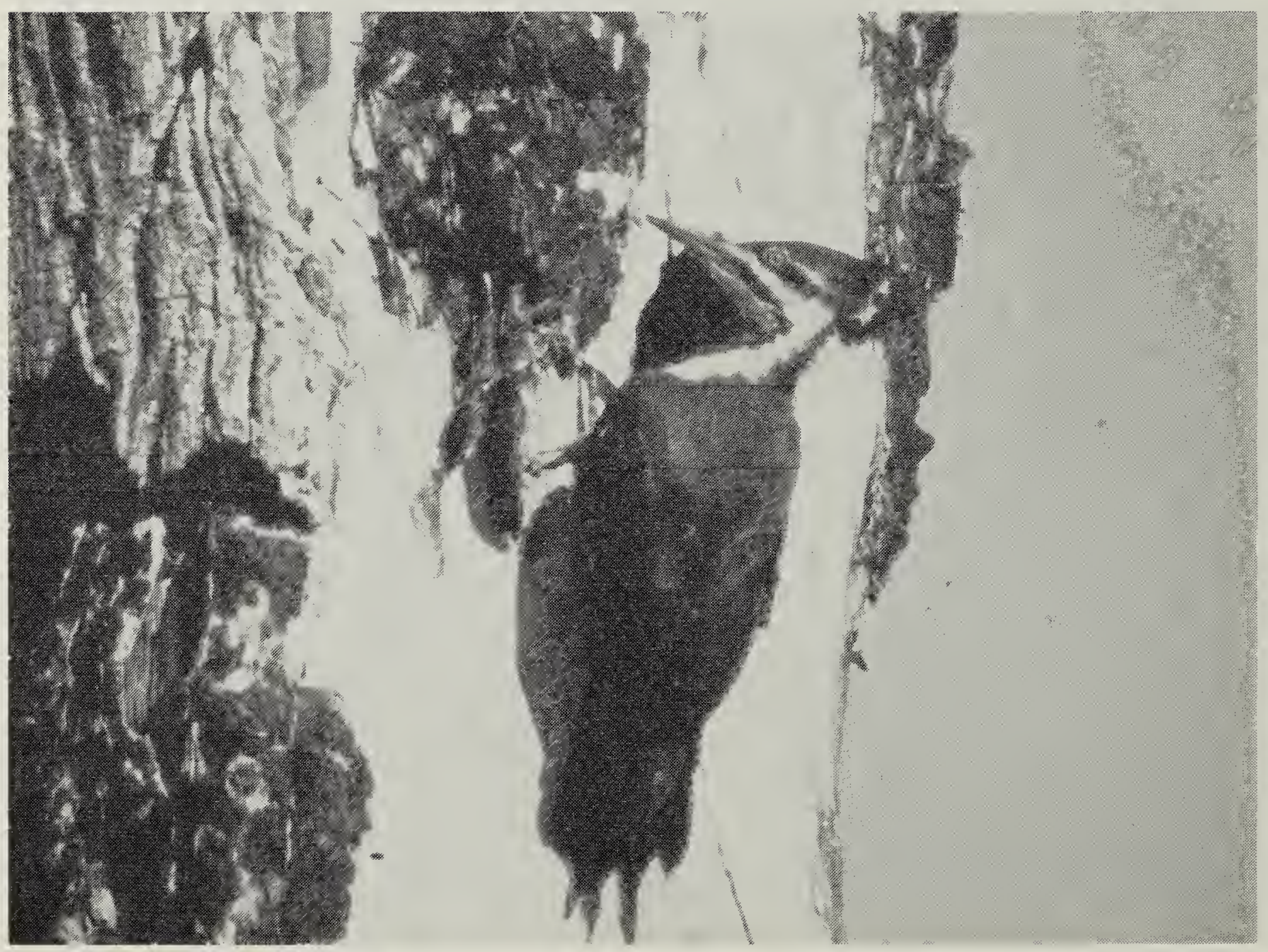

Figure 1. Pileated Woodpecker commencing regurgitation at nest hole.

Jim Slimmon 
unable to find the birds. Then on 17 May while we stood about $8 \mathrm{~m}$ from the snag, a Pileated glided by, landed beside a second hole and promptly entered.

Tapping the base of the stump failed to produce a Pileated on 21 May when the "Golden Eagles" (a group of senior citizens) visited the site, and failed again on the 23 rd when a Mayday Bird Count team was there. Yet on the 31 st the female showed herself. But patience had been essential. At least three minutes elapsed between tapping and appearance of the bird's head. In the evening of 10 June Bernie and Michael Gollop and I watched the birds change places at the nest. During incubation the male is reported to occupy the cavity at night. ${ }^{1}$

Between 8:00 and 8:30 a.m. on 13 June Jim Slimmon and I watched each woodpecker make a feeding trip. On 14 June the female made two feeding trips between 9:00 and 10:00 a.m. The bird would land beside the hole, hitch over to grasp its lower rim, commence regurgitative pumping, then disappear completely into the cavity. Slimmon took photographs, one of which caught regurgitation preliminaries when the bird's bill was slightly open. Whenever an adult was present, young called continuously. They could be heard clearly $12 \mathrm{~m}$ from the snag. The sounds issuing from the hole when a parent was inside suggested there were three nestlings. Finally we had proof of successful breeding.

The nest hole was about $4 \mathrm{~m}$ from the ground; $70 \mathrm{~cm}$ above that opening was another of the same size and shape. Courtship activity witnessed on the first visit had centered around this upper hole. Pileated Woodpeckers may often nest in the same stump for many years, with several old holes present, some occasionally being reused. ${ }^{1}$ Such may have happened here, and our 1987 observation may not have been the first nesting of the species in the snag.
The encounter with the courting pair was totally unexpected. My previous nesting observations of this hard-to-find woodpecker had been in the forests near Waskesiu, Emma and Candle Lakes. ${ }^{4}$ The new site, $47 \mathrm{~km}$ (29 mi.) northwest of Saskatoon, was $176 \mathrm{~km}$ (110 mi.) south of Emma Lake and represented a considerable southward extension of the breeding range depicted in The birds of Canada. ${ }^{5}$

This record is the third breeding reported south of the province's northern forests. The previous ones were in the west on Cranberry Island in the North Saskatchewan River near Big Gully Creek, and in the east in Good Spirit Lake Provincial Park (details given in table).

The site was in a narrow belt of riverine growth - anything but solid forest. At the nest stump, the vegetation measured only $100 \mathrm{~m}$ from river's edge to the adjoining cultivated field. Except at two coulee mouths, for a mile above and below the site, the belt was $25 \mathrm{~m}$ at the narrowest and a mere $150 \mathrm{~m}$ at the widest. The prominent trees, large black poplars and plains cottonwoods, were mostly scattered, with only a few in stands. Although aspen poplar and shrubs, including dense willow stands, were present, most of the vegetation was black birch. Many of the black poplars and cottonwoods were dead or dying and there was much deadfall, but where was there an adequate food resource for these big birds, two-thirds or more of whose intake is insects from diseased and decaying wood?

Short and Thomas gave the breeding area criteria as 60 acres of suitable habitat within a mile range or 300 acres of territory. ${ }^{2}$ Two large islands supporting a heavy growth, including numerous large trees, were likely also used by our birds to meet the implied foraging needs.

Listed in Table 1 are all the Saskatchewan Pileated Woodpecker nest records known to me up to December 1987. 
竎

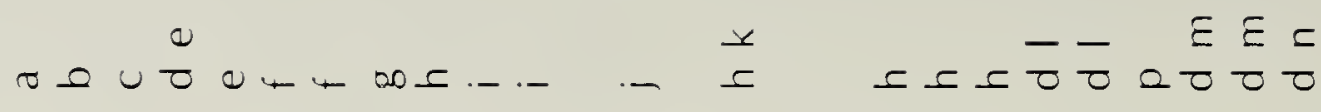

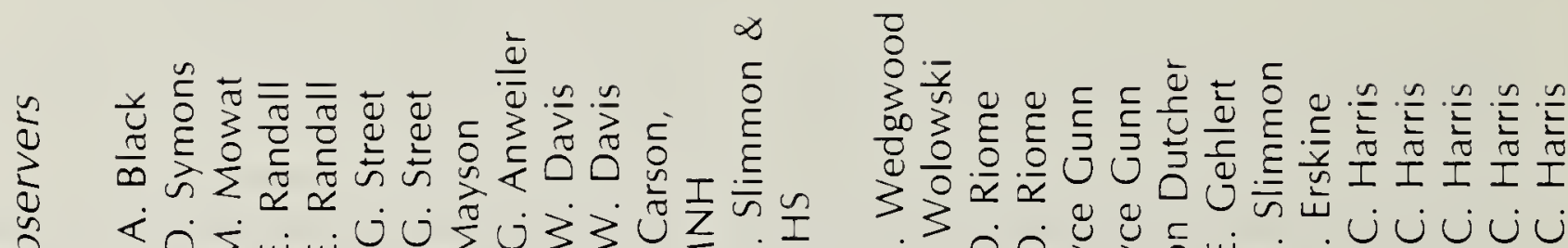

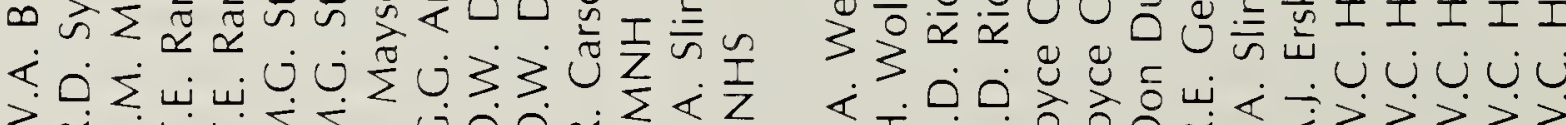

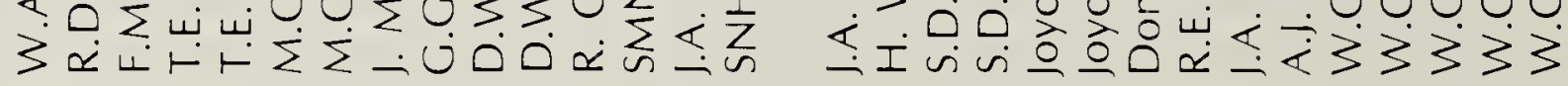

$\frac{\grave{c}}{\frac{\delta}{\delta}}$

$\stackrel{m}{+} \underset{m}{m}$

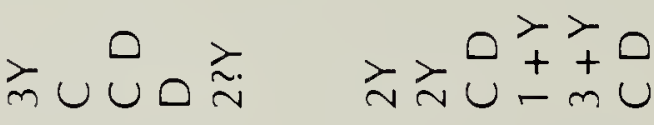

$\frac{\pi}{\frac{0}{0}}$

$\stackrel{2}{2}$

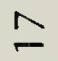

우움

$\therefore=N \underline{ \pm}$

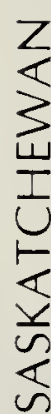

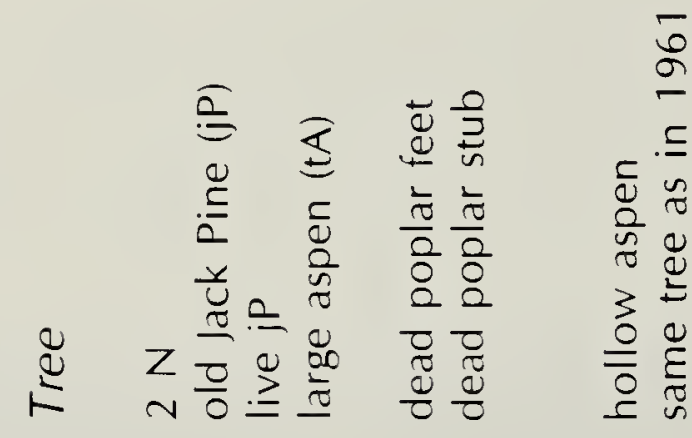

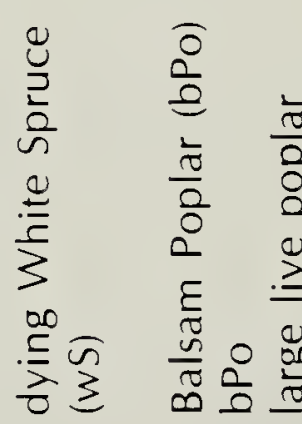

$\stackrel{\tilde{n}}{\stackrel{\leftrightarrow}{\Omega}}$

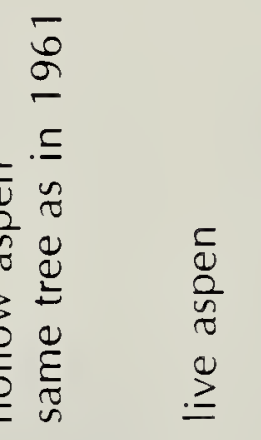

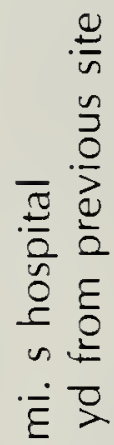

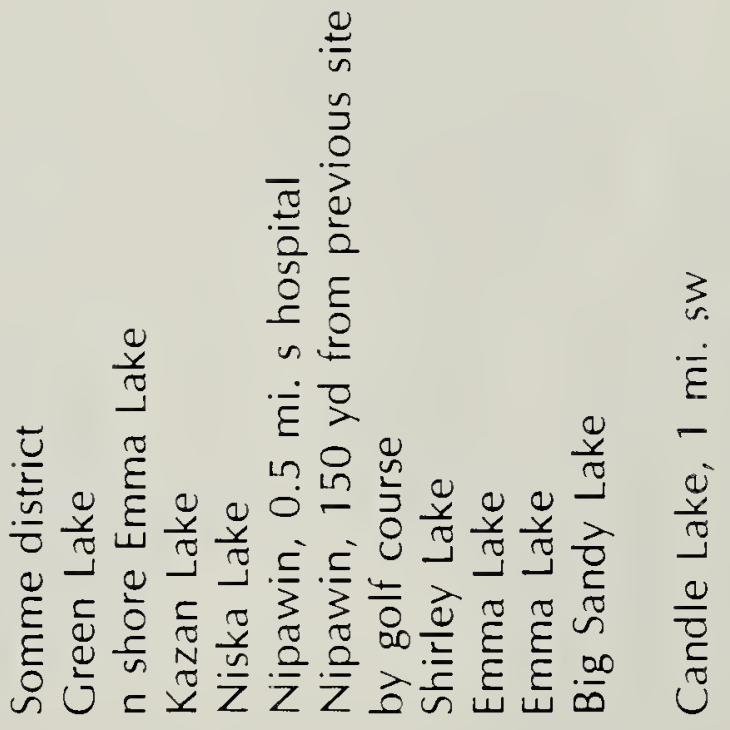

(5)

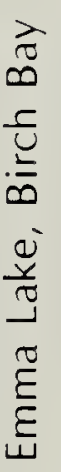

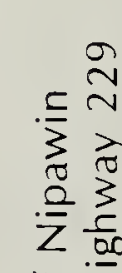

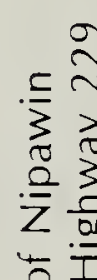

들
O
E̊
O

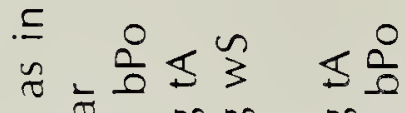

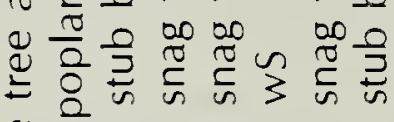

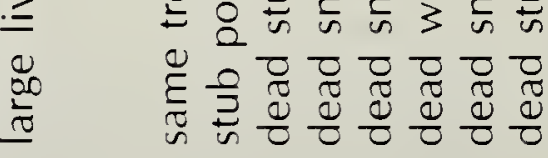

嵌

官

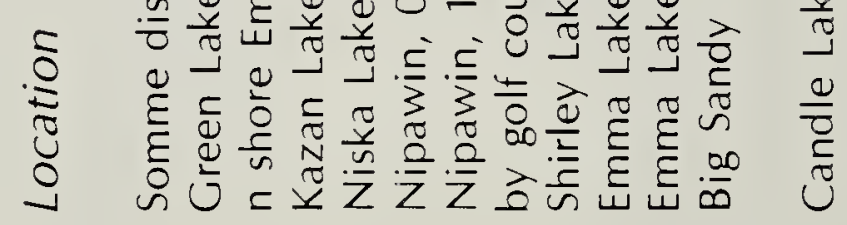

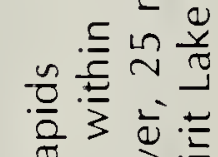
这.

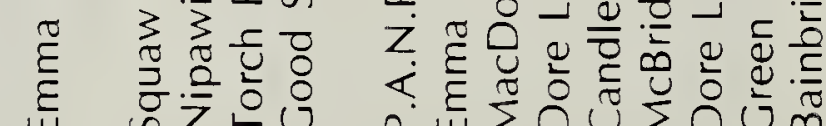

(4) $m$ O立

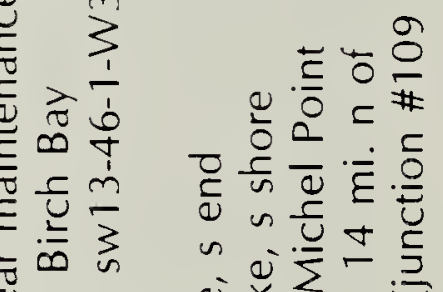

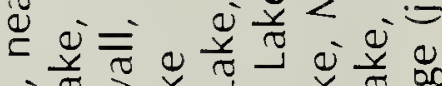

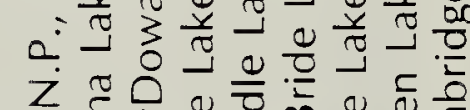

은

晨

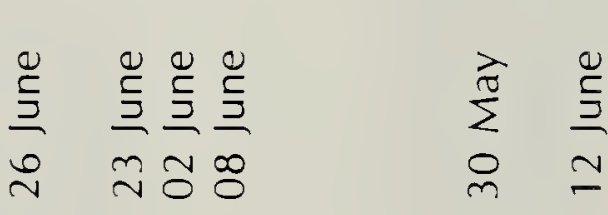

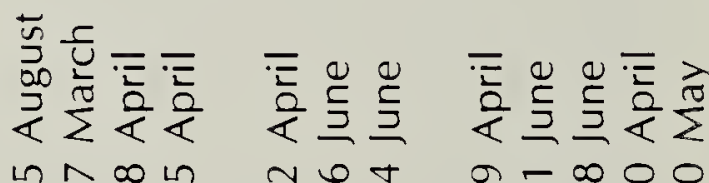

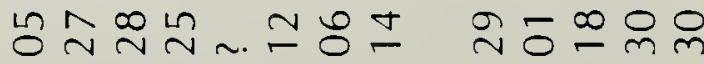

$\frac{\sqrt{2}}{\frac{\pi}{2}}$

$\frac{*}{2}$

బิ бू̆

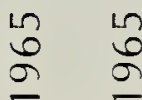

$\wedge \infty \infty$

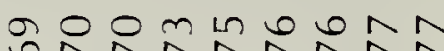

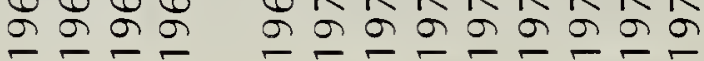




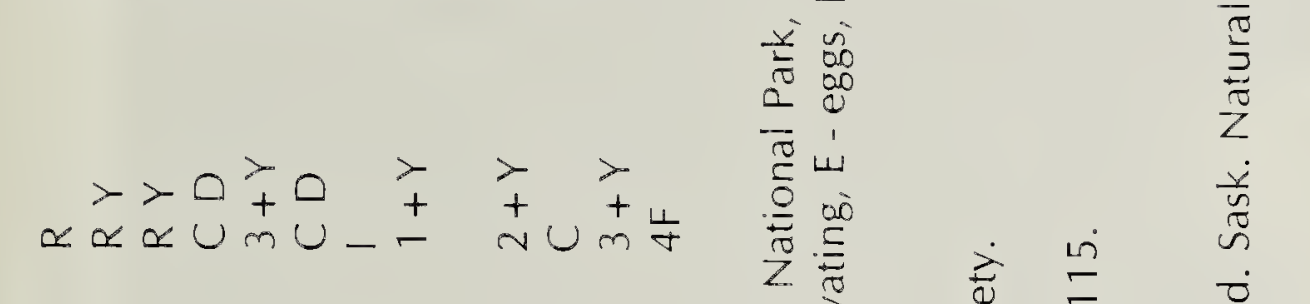

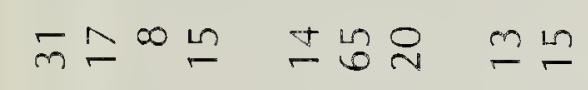

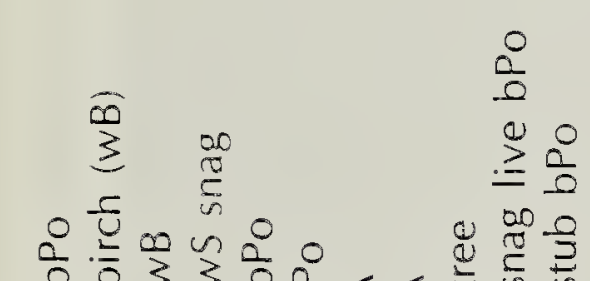

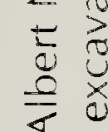

曾

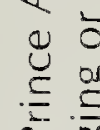

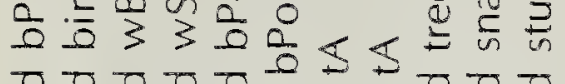

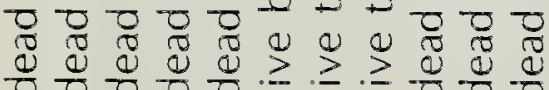

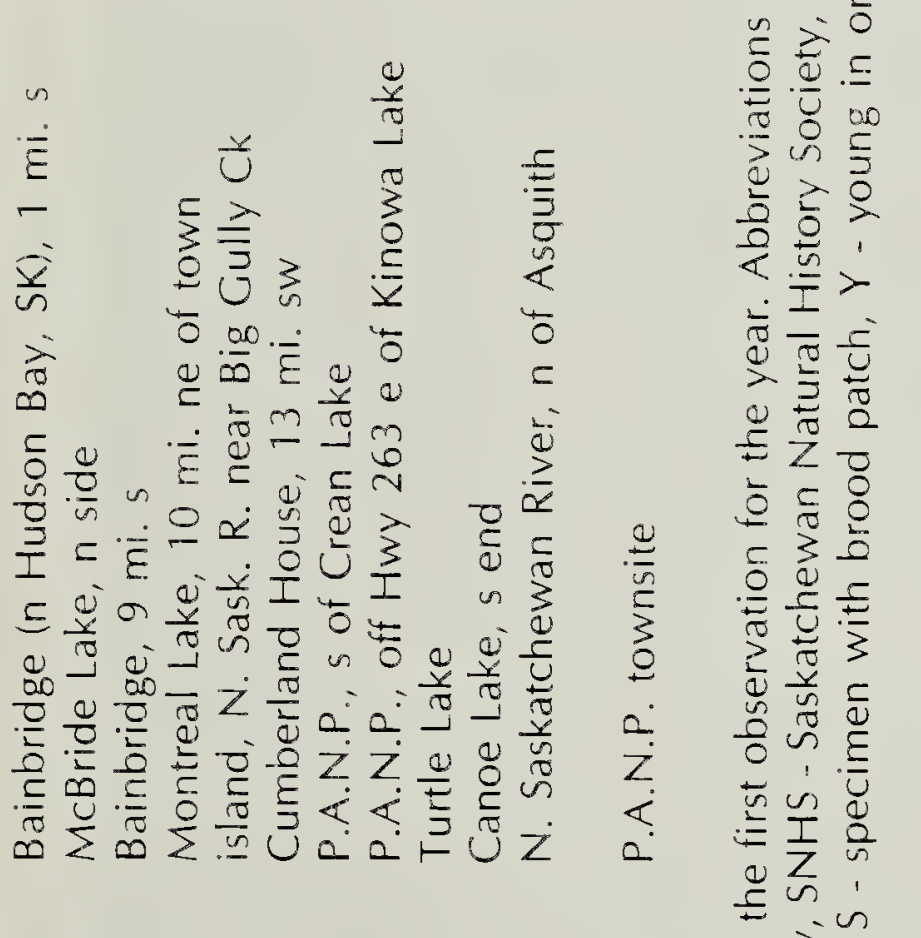

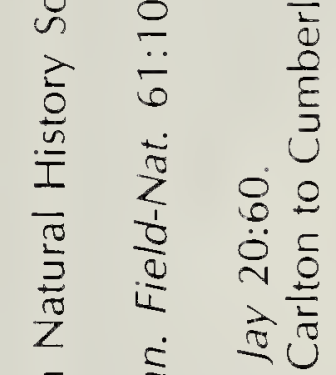

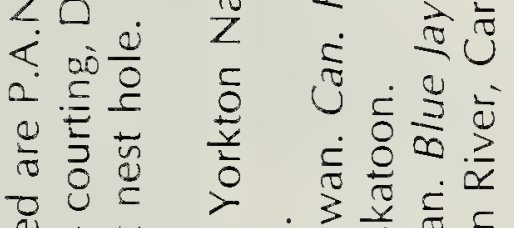

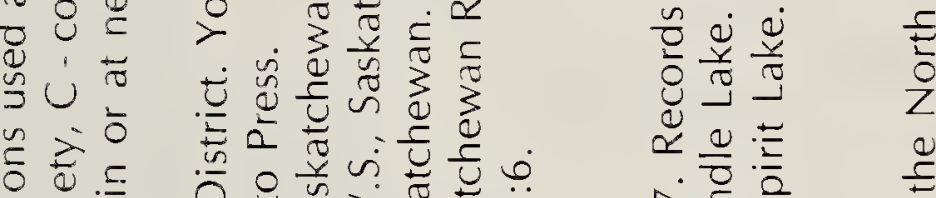
U.

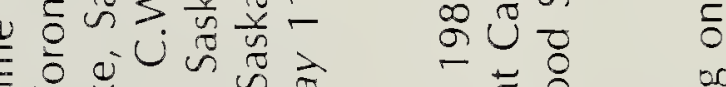
ही॰ ก

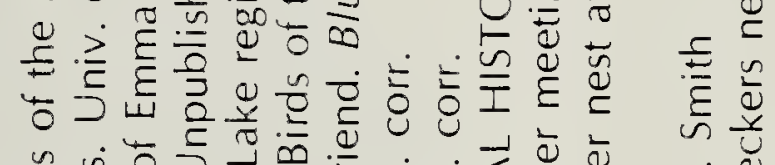

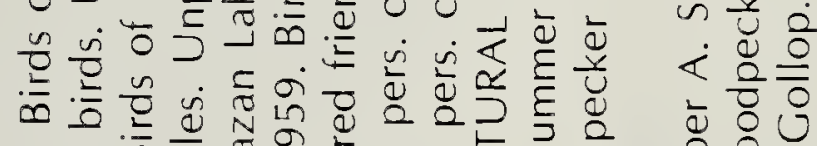

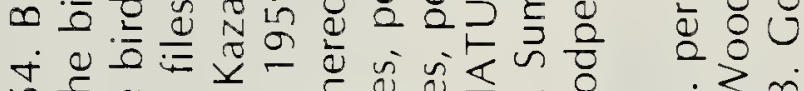

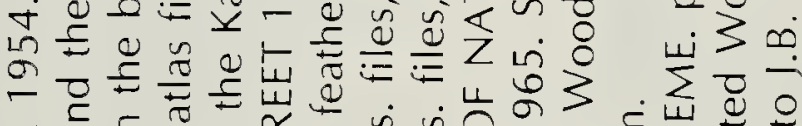
당

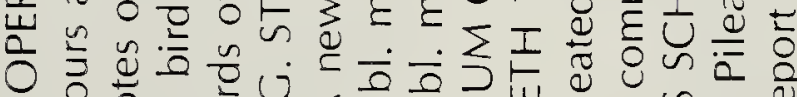

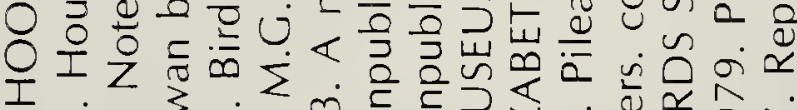

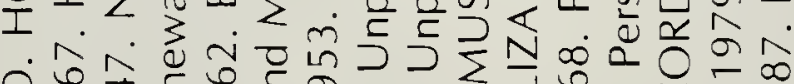

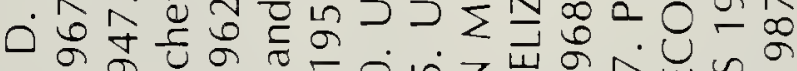
出

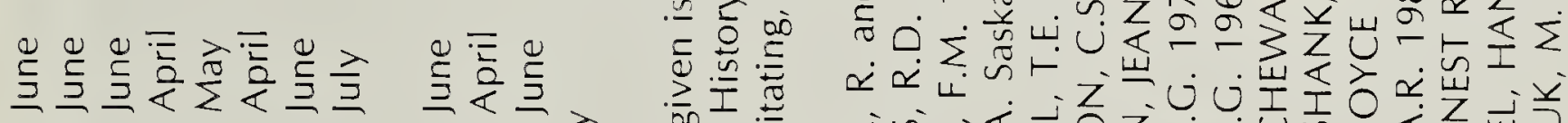

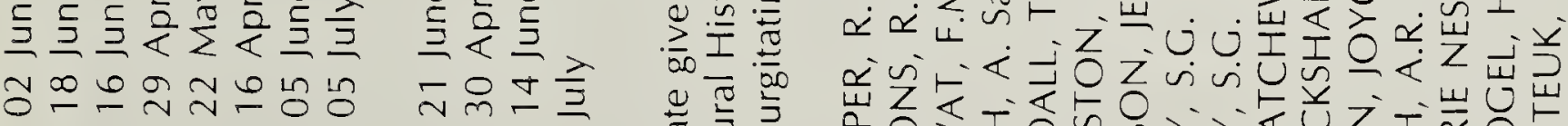

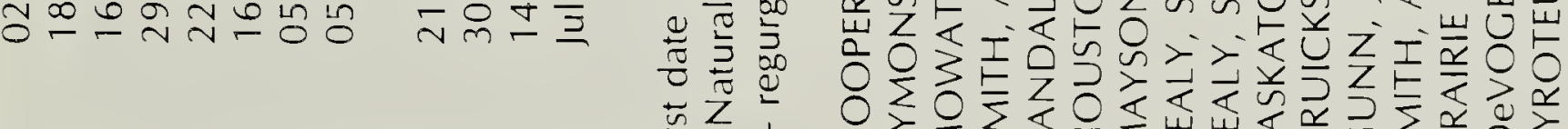

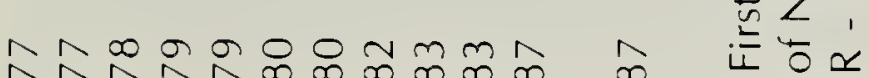
每

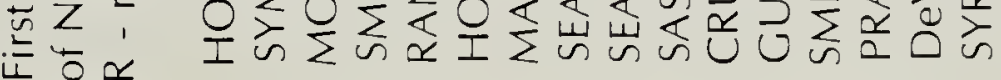

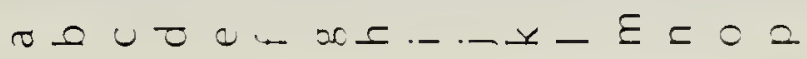


3 (1)

$\delta$
ह
$\frac{n}{n}$
ह

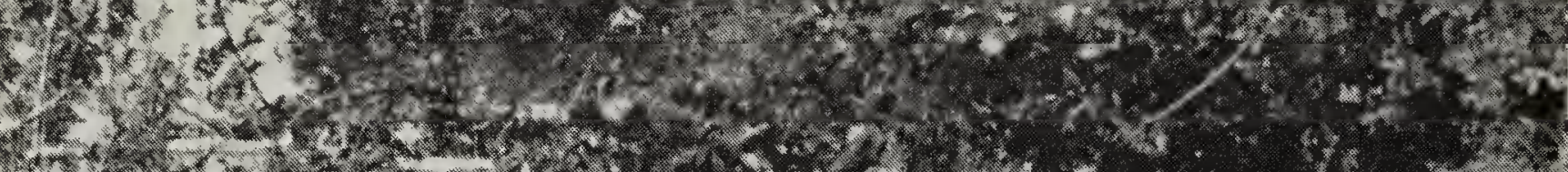

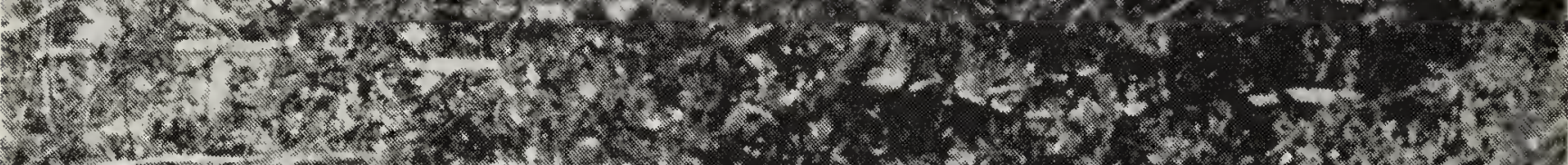

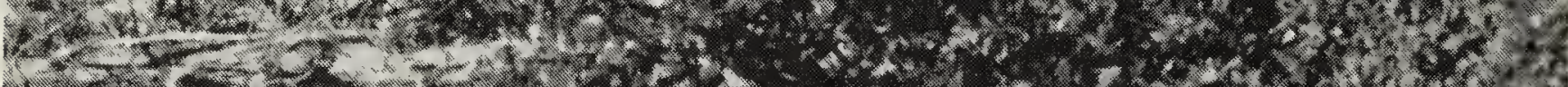

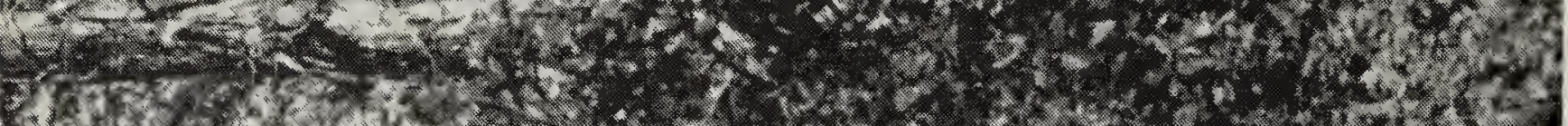

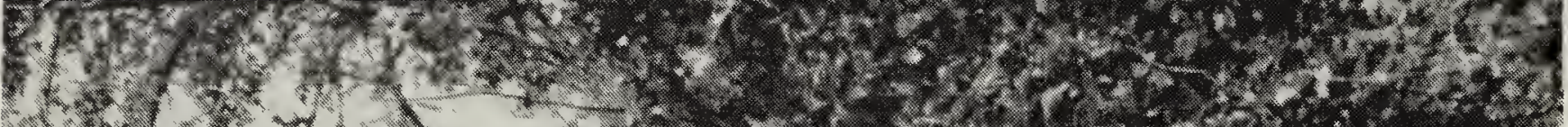

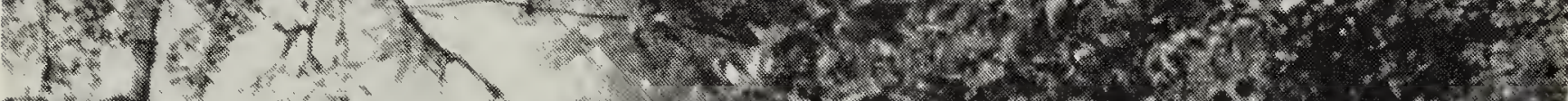

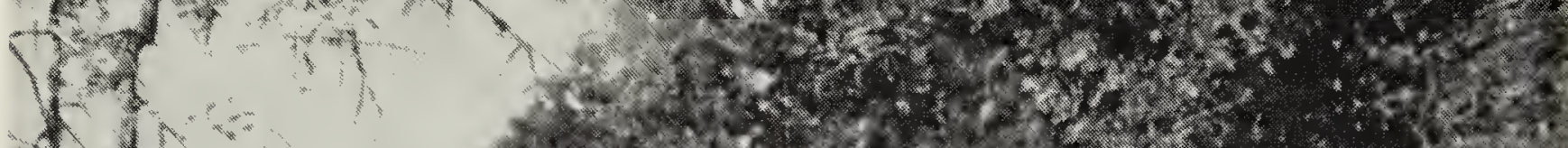<smiles>CC1CCCC1C</smiles>

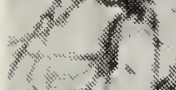

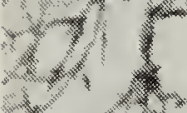

$+4$

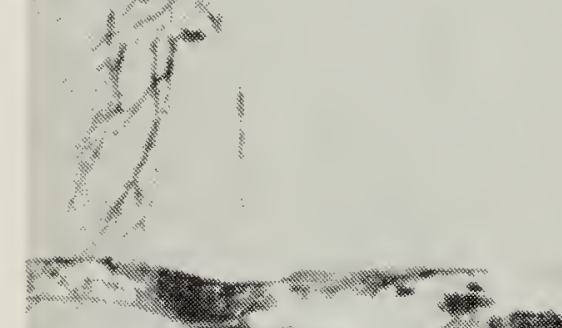

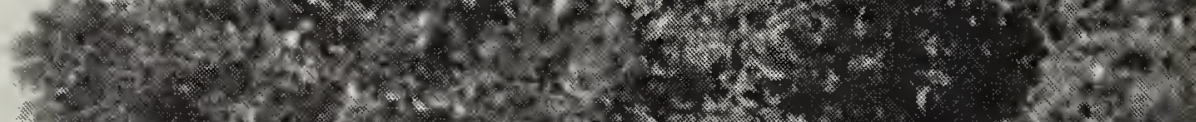
4.

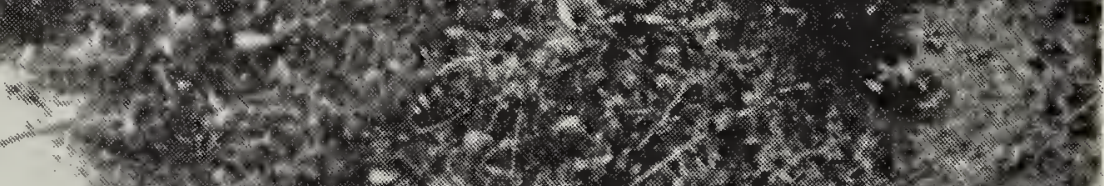

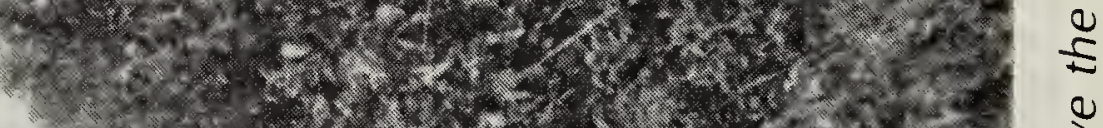

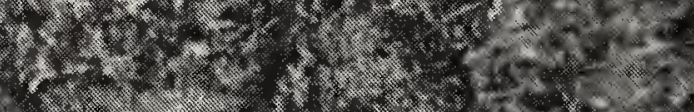

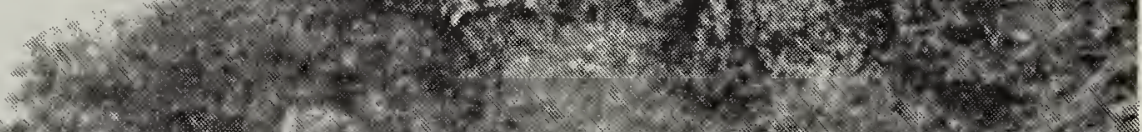

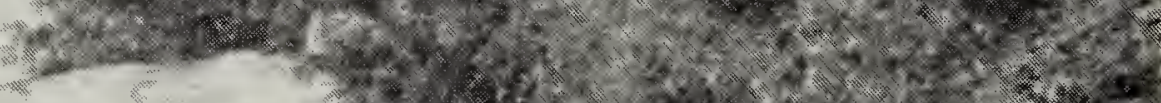

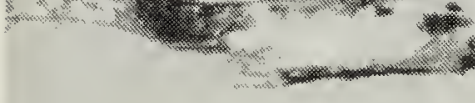

\section{$x^{2}+\sum^{*}+x^{2}$ $4+32+36+$ $7+3 x^{2}$}

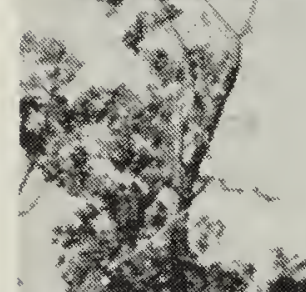

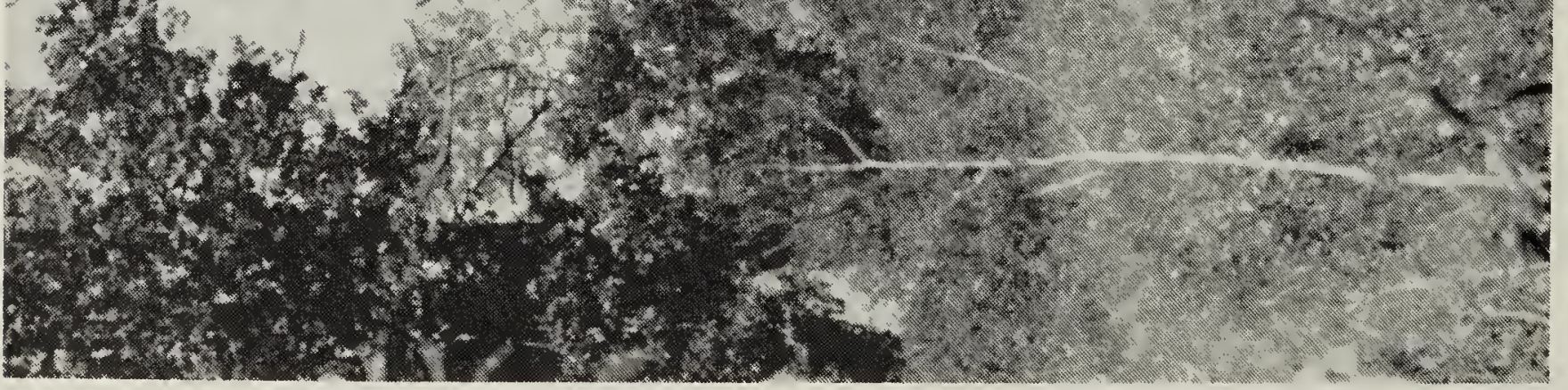

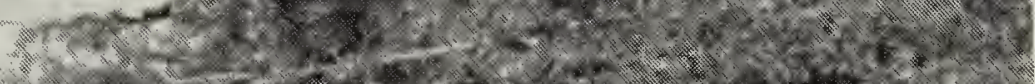
- 2.283.

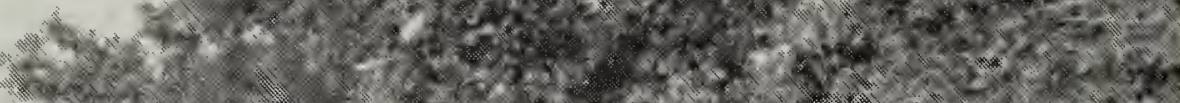

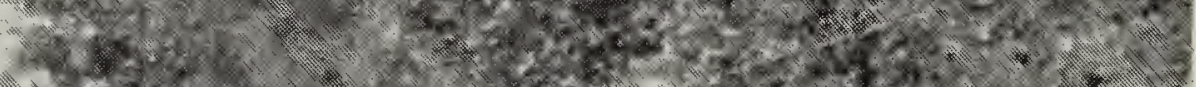

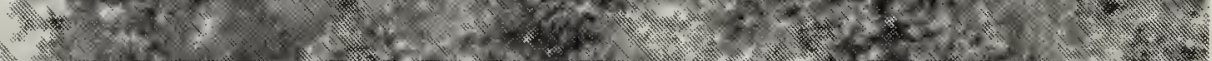

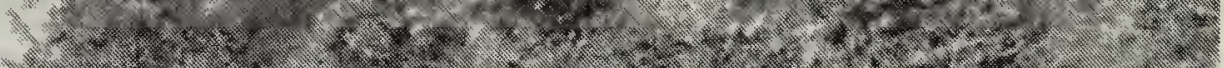

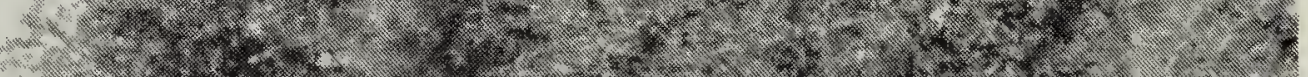

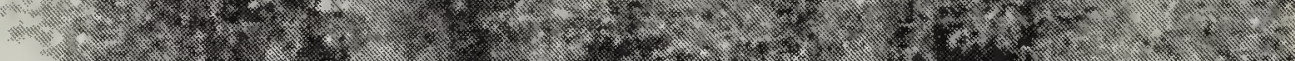

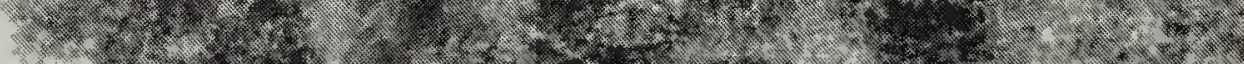

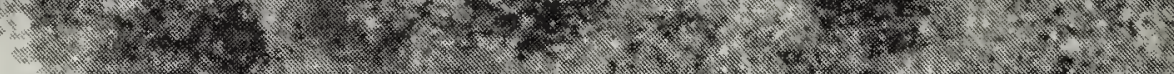

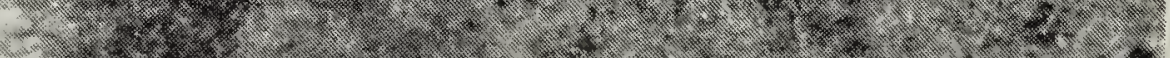

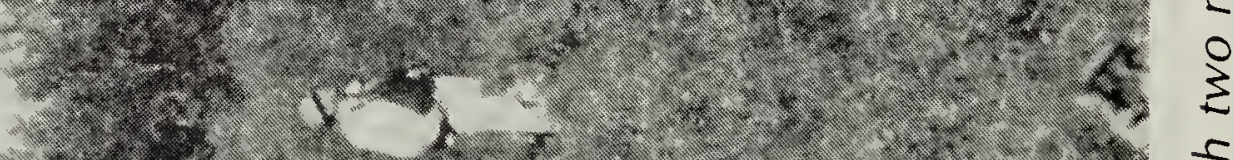

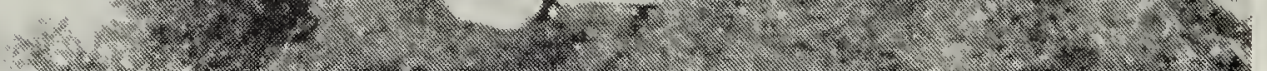

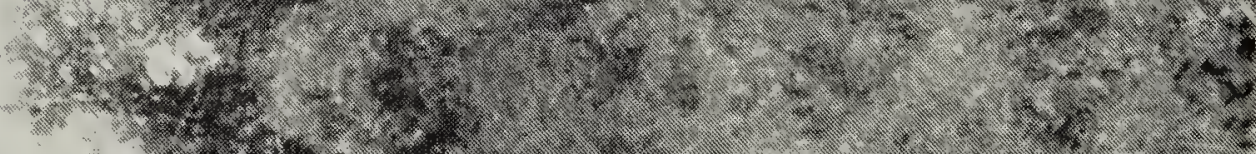

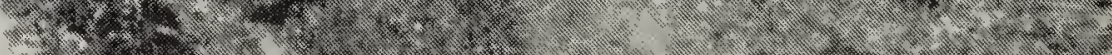

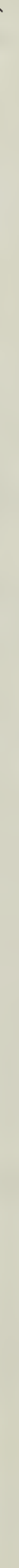


Scrutiny of the table suggested some patterns.

Apparent is the breeding birds' preference for snags of Populus tree species. Indicated, too, is a considerable variation in the height of the nest hole, from 6 to 65 feet. Although six courting and excavating observations were compressed into 5 days, 25-30 April, courting was seen all of 2 months earlier on 3 March. Was the cluster the result of peaking of woodpecker activity or of spring's flush of observers? Suggested by the data also is a reproduction rate of two to three nestlings per pair. But the major revelation is the importance to the species of large dead snags.

Additional details were available for a few of the observations. In one and possibly three instances the same snag was used more than once, and at two sites Pileateds were present for at least 2 years. A situation near water was noted four times. Possibly this was not a direct association, but rather resulted from the natural occurrence of large trees close to water. The woodpecker commonly digs its nest hole into the southeast quadrant of the tree; that orientation was remarked for three and the northwest for one of the reported cavities. ${ }^{2}$

Short described the three habitats for Pileated Woodpeckers as mixed deciduousconiferous forests, deciduous forests and second-growth woods, wherever some large trees can be found. ${ }^{1}$ Salt and Bent noted usual or preferred nesting sites were valley bottom lands, lowlands near water and swamp edges, always given some big, old trees. ${ }^{9} 1$ Second-growth woods, valley bottom lands and lowlands near water are each descriptive of the unlikely-looking Asquith site.

Three of the six habitats can be found south of the provincial forests. They occur in the valley of the North Saskatchewan, along portions of the South Saskat- chewan and other valleys, as well as in several parks. Pileateds have been reported a few times during spring and summer in the Saskatoon district (in valley bottom lands), in the Qu'Appelle Valley and in Moose Mountain Provincial Park. ${ }^{1} 3786$ Possibly these birds were local breeders and not the summer wanderers they were once presumed to be. ${ }^{3} 8$ Although it is uncommon, we could expect to find this impressive woodpecker breeding in these places.

On a fall visit to the Pileated Woodpecker site I was sorry to find a gravel pit operation had started in the adjoining field. Just a narrow band of bush stood between gravel equipment and the nest stump.

\section{Acknowledgements}

Breeding records were provided by Wayne C. Harris, personal records; Paul C. James, Saskatchewan Museum of Natural History, Museum files,; Spéncer G. Sealy, unpublished manuscript; Alan R. Smith, Canadian Wildlife Service, Saskatchewan Bird Atlas files; Merv Syroteuk, Park Naturalist, Prince Albert National Park, staff records. Jim A. Slimmon provided photographs and J. Bernie Gollop, C.W.S., proffered advice and suggested references. Cliff A. Matthews commented on identification of trees and N. Pern Cordery provided Blue Jay current index files. I greatly appreciate the assistance provided by these people.

'BENT, A.C. 1964. Life histories of North American woodpeckers. Dover Publ. Inc., N.Y. 334 pp.

${ }^{2}$ BULL, E.L. 1987. Ecology of the Pileated Woodpecker in northeastern Oregon. J. Wildl. Mgmt. 51(2):472-481.

${ }^{3}$ CALLIN, E.M. 1980. Birds of the Qu'Appelle, 1857-1979. Sask. Natural Hist. Soc. Spec. Publ. No. 13. 168 pp.

${ }^{4}$ GODFREY. W.E. 1950. Birds of the Cypress Hills and Flotten Lake regions, Saskatchewan. 
National Mus. of Canada. Bull. No. 120.96 pp.

${ }^{5}$ GODFREY. W.E. 1986. The birds of Canada. National Mus. of Canada. 595 pp.

${ }^{6}$ HARRIS, W.C. 1984. The autumn migration. Prairie provinces region. Am. Birds 38(2):215.

7 HOUSTON, C.S. and M.I. HOUSTON 1986. Additions to Callin's birds of the Qu'Appelle. Blue Jay 44(2):70-84.
${ }^{8}$ NERO, R.W. and M.R. LEIN 1971. Birds of Moose Mountain, Saskatchewan. Sask. Natural Hist. Soc. Spec. Publ. No. 7. 55 pp.

${ }^{9}$ SALT, W.R. and J.R. SALT 1976. The birds of Alberta. Hurtig Publ., Edmonton. 498 pp.

10 SASKATOON NATURAL HISTORY SOCIETY n.d. Saskatoon field notes. Bird record file (unpubl.)

11 SHORT, L.L. 1982. Woodpeckers of the world. Delaware Mus. of Natural Hist. 676 pp.

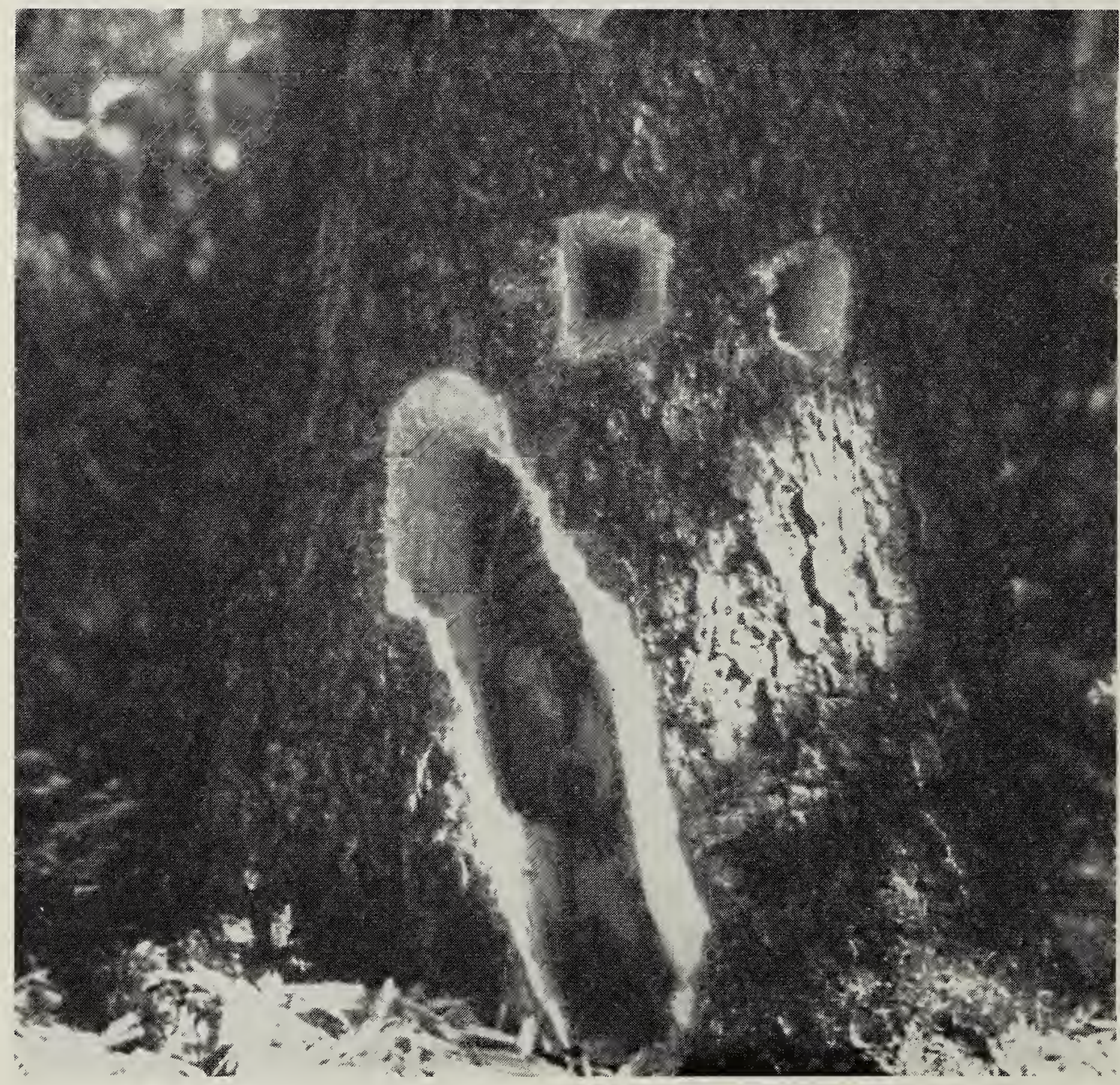

Pileated Woodpecker excavations in White Spruce, note squared holes.

G.J. Smith 